\title{
Assessments of Amino Acids, Ammonia and Oxidative Stress Among Cohort of Egyptian Autistic Children: Correlations with Electroencephalogram and Disease Severity [Corrigendum]
}

\author{
Saleem TH, Shehata GA, Toghan R, et al. Neuropsychiatr \\ Dis Treat. 2020;16:11-24.
}

The authors advised that the funding section was incorrectly presented in the original article and was missed during the revision process.
On page 22, In the section Funding, the correct statement should read as follows:

\section{Funding}

The current research was funded by South Valley and Assiut Universities, Faculties of Medicine, Egypt.

\section{Publish your work in this journal}

Neuropsychiatric Disease and Treatment is an international, peerreviewed journal of clinical therapeutics and pharmacology focusing on concise rapid reporting of clinical or pre-clinical studies on a range of neuropsychiatric and neurological disorders. This journal is indexed on PubMed Central, the 'PsycINFO' database and CAS, and is the official journal of The International Neuropsychiatric Association (INA). The manuscript management system is completely online and includes a very quick and fair peer-review system, which is all easy to use. Visit http://www.dovepress.com/testimonials.php to read real quotes from published authors. 